\title{
The Application of Self-Management Technique and the Improvement Student's Learning Responsibilities
}

\author{
Romia Hari Susanti* \\ Guidance and Counseling Program \\ Universitas PGRI Kanjuruhan Malang \\ Malang, Indonesia \\ *romi@unikama.ac.id
}

\begin{abstract}
Learning responsibility is a person's attitude to be willing and able to complete all the duties and learning tasks given and all the consequences with full awareness. This responsibility is obtained through a learning process and regular practice to direct students. Self-management is a technique that directs students to regulate their own behavior, determine target behavior, monitor, select procedures to be applied, carry out these procedures and evaluate learning outcomes. This research applies of self-management techniques through the Pre-Test and Post-Test One Group Design to increase awareness of their learning responsibilities. The results of the pretest and posttest data analysis of this study indicate a change in learning responsibility with a different value (z) of $-2,207$ which is evidenced by the ability of students to manage their own behavior, determine target behavior, monitor, and evaluate learning outcomes.
\end{abstract}

Keywords—self-management, learning responsibility

\section{INTRODUCTION}

The teaching learning activity is the most fundamental activity in the entire educational process. Learning is an individual's process of interaction in the use of senses of learning objects and environments through a series of reading, observing, listening, and mimicking activities that produce behavior, changes in understanding, habits, skills, or attitudes intended to comprehend scientific materials. In other words, education is not only producing smart or intelligent individuals but also implanting attitudes and personalities that fit in to the values andnormsapply in society.

Junior High School students are categorized at the early stages of adolescence, the transition from dependent childhood to the development of responsibility period [1]. Awareness of responsibility needs to be developed through habituation because it is not a genetic trait that has existed in every individual since birth. Students can learn responsibility from various aspects of environment: family education, school education and community education. As a maturing process, the objective of education is to form a student so that he can think maturely through the process of changing a better attitude, regulating himself and forming the responsibility of his or her duties asa student which is learning.

A conscious attitude toward learning responsibilities can be characterized as follows: (1) doing tasks regularly without being told, (2) being able to explain reasons for learning activities, (3) never blame others in the learning process, (4) being able to find alternative ways in learning choices, (5) being able to do his or her own duty gladly, (6) being able to make different decisions from others, (7) having a strong interest in learning, (8) respecting and honoring school rules, (9) being able to concentrate on learning, and (10) have responsibility for school performance. Reflection of the student's learning responsibility needs a good self-organizing ability in order to achieve a good learning results or achievements.

The attitude to be willing and able to complete all the learning responsibilities that have been given along with all the consequences that a student must consciously accept is the definition of learning responsibility. Through a routine process of learning and practice habits, a sense of responsibility can be grown in students to manage and direct themselves. Selfmanagement is a technique that directs students to regulate their own behavior, define target behavior, monitor and select the procedures to be implemented, apply the procedure and evaluate its learning.

Gie states that there are 4 aspects of the self-management in learning for the students: (1) self-motivation, (2) selforganization, (3) self-control, and (4) self-development [2]. In the implementation process of self-management technique, counselors assist students in developing plans that include selfmonitoring, self-assessment, self-strengthening, and identifying behaviors to be achieved. Through this technique, it is expected that students will be able to self-organize, self-monitor and self-evaluate themselves on the consequences of the learning responsibility in order to achieve a better change of habits. 


\section{Methodology}

The study used pre-experimental experiments design because in this study there are outside variables that influence the formation of dependent variables. The study does not use control variables and random selection of samples. The study uses Pre-Test and Post-Test One Group Design where in this experiment observation was made twice. One is conducted before the experiment called pre-test and the other is after the experiment called post-test to find out the difference before and after treatment.

The treatments given are the application of selfmanagement technique in six meetings in for six weeks. As for the experimental stages are as follows:

\section{A. Pre-test}

The purpose of pre-test is to know the level of students' learning responsibility before treatment which is selfmanagement technique.

\section{B. Treatment}

Treatment given is the application of self-management technique to improve Junior High School students' learning responsibilities.

\section{Post-test}

The purpose of post-test is to determine the level of success after the treatment is given, and the effectiveness of selfmanagement technique in improving Junior High School students' learning responsibilities (experiment members)

Subjects sampling technique used in this study is purposive sampling. The selection of subjects groupsis based on predetermined and foreknowledge characteristics in terms of characteristics and attitudes. Based on predetermined characters and attitudes set by the researcher, there were 6 students of seventh grade junior high school who had a low learning responsibilities. The awareness level of subjects'learning responsibilities can be identified by using an inventory of responsibility awareness which has been already tested in terms of its validity and reliability with Cronbach's alpha $0.874>0.60$ which means the instrument is a highly reliable instrument.

\section{RESULTS AND DISCUSSION}

Pre-test data of students' learning responsibility awareness on 36 students of VII C resulted on 6 students who had low awareness of learning responsibility which become the subjects of the study.

\section{A. Treatment}

1) The first meeting (ice breaking): The activity starts with a game named "It's me". The purpose of the game is to develop good relationships between the researchers and the students, so that the students may feel more at ease.
2) The second meeting (treatment): Forming of report card is the core activity at this meeting. Researcher also explain the objectives of the experiment through group guidance, and provide the introduction materials of self-management technique and its stages which are self motivation, self organization, self control, and self development.

3) The third meeting (treatment): Implementation of selfmanagement techniques.In this meeting, students are taught about self-monitoring, evaluation, and affirmation activities.

4) The fourth meeting (treatment): At this stage, students are asked to fill out a paper on the negative effects of irresponsible behavior in learning and determining strategies to overcome it.

5) The fifth meeting (treatment): In this meeting stimulus control activity is given to the students. They are also provided some examples of self-control in real life situation.

6) The sixth meeting (treatment): The activity carried out by the researcher is to provide an explanation of what selfreward is and appropriate application to achieve desired behavior. At the end of this meeting, post-test is given to the research subjects.

Post-test are conducted to identify the success rate during treatments and to recognize changes in students' learning responsibilities awareness. The study does not use control groups so that the data can be described as follows:

- AMD on pre-test scores 126, and on post-test scores 149. AMD improves his/her score by 23 points.

- ANL on pre-test scores 125 , and on post-test scores 145. ANL improves his/her score by 20 points.

- ENKZ on pre-test scores 124, and on post-test scores 142. ENKZ improves his/her score by 18 points.

- HIR on pre-test scores 126, and on post-test scores 144. HIR improves his/her score by 18 points.

- IR on pre-test scores 104, and on post-test scores 144. IR improves his/her score by 40 points.

- TPS on pre-test scores 116, and on post-test scores 138 TPS improves his/her score by 22 points.

Pre-test data on 6 students show a minimum score of 104 and a maximum score of 126. After treatments of selfmanagement technique to increase the awareness of learning responsibility is given, the post-test data show a minimum score of 138 and a maximum score of 149. Based on WSRT analysis, the underlying value $(\mathrm{z})$ after treatments and before treatments is -2.207 .

The results of pre-test and post-test data analysis using Wilcoxon test show sig.(2-tailed) $0.027<0.05$ which means the self-management technique can improve the learning responsibility awareness of Junior high school students and can be accepted as such at a significant level of 5\%. 
Based on wilcoxon's test calculations, it could be stated that the early conditions of subjects' learning responsibilities awareness levels are low on average while post-test data indicate that the students' learning responsibilities are becoming moderate. Researcher gives the treatment of selfmanagements techniques because students feel a lack of confidence in their abilities and students' lack of awareness on the importance of fulfilling student duties in accordance with Sudani's opinion, which states that students 'low responsibility on learning is affected by several factors: (1) students' lack of awareness on the importance of full filling their rights and duties that are their responsibilities, (2) lack of confidence in their abilities, and (3) guidance and counseling services performed by the Counseling Teacher in handling responsibility behaviors have not been optimally implemented [3].

The use of group guidance with the self-managements technique in this research as an alternative to help to improve students' learning responsibilities based on Komalasari's opinion self-managements is one of the techniques of behavioral approach which believe that behavior can be learned. The awareness of learning responsibility is an attitude that has to be trained toward students to become a positive habit [4]. One of the objectives of the behavior approach is to help students dispose of self-destructive or maladaptive responses and learn appropriate new responses. It may be defined that behavioral approach can change maladaptive behavior, such as irresponsible learning into an adaptive behavior such as having an awareness of learning responsibility.

The self-management technique points to a technique in cognitive behavior therapy designed to help students control and alter their own behavior in a more effective way. Through this technique the student is trained to organize his or her behavior in order to manage behaviors, thoughts and feelings of their own for the purpose of learning. Gunarsa suggests that self-management is a procedure where students use their skills and self-management techniques to deal with the problem, researched in this study, which is a learning responsibility [5]. Gie declares that self-management means encouraging yourself to move forward to manage all elements of personal ability, controlling the ability to accomplish good results and develop various aspects of personal life to be more perfect [2]. As for other changes of students following the treatment, students begin to develop routine study schedules and perform unimpeded tasks that also fit the opinion of Adiwiyoto, which explains that self-management is a process by which individuals organize their own behavior [6].

Gie explains, self-management is a process in which after a person sets the goal of life for himself, he has to manage and organize as good as possible to achieve the goal [2]. The subject of this study had a shift in awareness of responsibility which previously had a low level of awareness to a moderate level of awareness attributable to the hypothesis testing results of the Zcount value of 2,207 and the value of the Ztable at a significance level of $5 \%$. The self-management technique is considered effective for raising students' awareness of learning responsibility because the whole subject of research is seen to be enthusiastic in joining all activities during six meetings, active in speaking out and questioning other members, creating new stimulus and reducing all possibilities that make them neglect the learning responsibility. The essence of the treatment is that students acquire new knowledge and are able to reduce irresponsible behavior in learning.

\section{CONCLUSION}

This research stage begins with giving pre-test to class VII $\mathrm{C}$, then from the pre-test results, the data of students who have a low level of awareness of responsbility are obtained and used as a basis to decide the research subject. The experiment was conducted six times during both on counseling-hours and off counseling-hours, and was given only to an experimental group without a control group. During the experiment, student are guided and directed to pass through the stages in the implementation of self-management technique including selfmotivation, self-organization, self-control, self-development and reflection. Next up at the end of the stages, students are given post-test to determine if there an increasing on awareness of students' learning responsibility after treatment to prove that the use of self-management technique is effective to raise the awareness of learning responsibility for junior high school students. According to wilcoxon's test analysis result, the use of self-management technique is effective to improve the awareness of learning responsibility for junior high school students. The changing behavior of the students' learning responsibility is also illustrated by the subjects' behavior who previously difficult to concentrate during class, now they can focus more on the teacher's explanation because of knowing the essential meaning of learning and also becoming more active during the learning process.Previously, they only studied when they were having a test, now they actively study everyday due to the learning schedule that has been formed.

Based on the conclusions drawn in this experiment through the application of the self-manajement technique to improve the awareness of learning responsibility for junior high school students, some suggestions should be considered as follows:

\section{A. Technical Application Suggestion}

- The counselor needs to motivate students during treatment process such as asking reflective questions that lead students to every stage of self-management technique.

- The counselor needs to provide sufficient time between one treatment and another so that the results obtained by the students are purely from the results of the treatment.

\section{B. Development Advice}

Suggestions for researchers who are interested in developing self-management technique could then use control group in the implementation of the experiment so that there can be seen differences in increasing awareness of students' 
learning responsibilities between treatment and non-treatment groups. In addition, the post-test used to measure the increasing awareness of students' learning responsibilities can be given per-meeting so that it can be seen that the increase in awareness of students' learning responsibilities is not temporary after being given treatment only.

\section{REFERENCESS}

[1] E. Hurlock, Psikologi Perkembangan: Suatu Pendekatan Sepanjang Rentang Kehidupan. Terjemahan Istiwidayanti, Soedjarwo, Jakarta: Erlangga, 2000.

[2] T. L. Gie, Cara Belajar yang Baik bagi Mahasiswa edisi kedua, Yogyakarta: GadjahMada University Press, 2000.

[3] Sudani, Penerapan Konseling Eksistensial Humanistik Teknik Pemodelan Untuk Meningkatkan Perilaku Tanggung Jawab Belajar Siswa Kelas VIII E SMP Negeri 1 Sukasada, J. of JBK, 2013.

[4] Komalasari, Teori dan Teknik Konseling, Jakarta: PT. Indeks, 2011.

[5] D. S. Gunarsa, Konseling dan Psikoterapi, Jakarta: Gunung Mulia, 2004.

[6] A. Adiwiyoto, Melatih Anak Bertanggung Jawab, Jakarta: Mitra Utama, 2001 . 